\title{
INCREASE OF CANINE LEISHMANIASIS IN A PREVIOUSLY LOW-ENDEMICITY AREA IN TUNISIA
}

\author{
CHARGUI N.*, HAOUAS N.*, GORCII M.*, AKROUT MESSAIDI F.**, ZRIBI M.** \& BABBA H.*
}

\section{Summary :}

An epidemiological study of canine leishmaniasis (CanL) was carried out in nine districts of Sfax, in the southern central part of Tunisia. Sera from 250 dogs were tested by two serological methods: the indirect immunofluorescence antibody test and the counter-immunoelectrophoresis. Seven to eight months later, before the next season of transmission, seropositive dogs from the first test were re-examined and a second sampling was performed. Infection status was assessed by serology and by other methods. PCR, in vitro culture and direct examination were applied on blood and other samples (bone marrow, liver, lymph node, spleen and cutaneous biopsies). The seroprevalence of the infection in dogs was $6 \%$. Infection was then confirmed by at least one other method. The PCR is the method which agreed most with serology, all seropositive dogs were found PCR-positive. The sensitivity of the direct examination and the culture was only $33 \%$ and $55 \%$ respectively as compared with serology. A similar value of seroprevalence has been observed previously in Sousse, in the northern central part of Tunisia. The present report suggests a significant increase of Canl in the Sfax area and confirms that the disease is continuing to move southwards in Tunisia.

KEY WORDS : canine leishmaniasis, epidemiology, prevalence, Tunisia, serology, PCR.

T $\mathrm{n}$ n Tunisia, human visceral leishmaniasis is due to L. infantum (Kinetoplastida: Trypanosomatidae) and transmitted mainly by the infected bite of females of Phlebotomus (Larroussius) perniciosus. Dogs (Canis familiaris) are known as the main reservoir of human visceral leishmaniasis since the discovery of the first case of canine leishmaniasis (CanL) in Tunisia by Nicolle and Comte (1908). Over many decades, it was notified mainly in the northern part of Tunisia with a few or no cases described in the centre and the south. The recent spatial distribution of the infection incidence of human cases showed an aggregation of cases in the northern part of the country and a spread of the infection to other areas of Tunisia. Indeed, ten cases/year were recorded before 1980 and 100-150 cases/year is the incidence recorded since 1994 in the north of

\footnotetext{
* Laboratoire de Parasitologie-Mycologie, Faculté de Pharmacie, Monastir, Tunisie.

** Centre d'Hygiène de Sfax, Tunisia.

Correspondence : Babba Hamouda, Laboratoire de ParasitologieMycologie 99UR/08-05, Faculté de Pharmacie, 1, rue Avicenne, Monastir, Tunisie. Tel.: +216 73448666 - Fax: +216 73461830 .

E-mail: hamouda.babba@gnet.tn
}

Résumé : Augmentation de la pRÉVAlence de la leishmaniose CANINE DANS UNE RÉGION À FAIBLE ENDÉmiCITÉ EN TUNISIE

Sfax se situe dans une région de la Tunisie qui a été longtemps considérée comme exempte de la leishmaniose canine (LCan). Le but de ce travail épidémiologique est d'étudier la prédominance de la LCan dans neuf délégations de Sfax. Des sérums de 250 chiens ont été prélevés et examinés par deux méthodes sérologiques, I'Immunofluorescence indirecte et l'électrosynérèse. Huit mois plus tard, un deuxième prélèvement a été effectué sur les chiens séropositifs. L'infection a été évaluée une autre fois par sérologie et par d'autres méthodes (PCR, culture in vitro et examen direct). Une séroprévalence de $6 \%$ a été trouvée. L'infection a été ensuite confirmée par d'autres méthodes. La PCR est la méthode qui concorde le plus avec la sérologie, avec une sensibilité de $100 \%$. Les sensibilités de l'examen direct et de la culture n'ont été que de $33 \%$ et $55 \%$ respectivement. Ce présent travail suggère une augmentation de l'infection dans cette région et confirme qu'elle est en train de s'étendre vers le Sud de la Tunisie.

MOTS CLÉS : leishmaniose canine, Sfax, Tunisie, sérologie, PCR.

Tunisia (Besbes et al., 1994; Belhadj et al., 1996; Bouratbine et al., 1998). A spread of the disease from the north to centre and the south has been observed (Ayadi et al., 1991; Besbes et al., 1994; Ben Salah et al., 2000). This current status of the human disease in Tunisia may be the result of the establishment of a stable transmission cycle of Leishmania. The ecological modifications connected to changes in land use have probably induced an increase in vector and reservoir densities as well as changes in their geographical distribution (Aoun et al., 2004; Ghrab et al., 2006). In this study we assessed the prevalence of CanL in districts of Sfax governorate, south-central Tunisia, previously known as a low-endemicity area for this infection.

\section{MATERIALS AND METHODS}

\section{CANINE POPULATION}

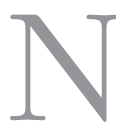

ine rural districts of Sfax governorate were selected for the study at the same time as an antirabic vaccination operation between April 
and June 2003; the six urban districts of Sfax were not concerned with this study. In initial study, venous blood samples were taken from the foreleg from $250 \mathrm{dogs}$ for serological studies. Animals were examined for signs of disease (Dedet et al., 1973; Ben Said et al., 1992), including dermatological and ocular changes, loss of weight, apathy, lymph node and spleen enlargement. Seven to eight months later, before the next season of transmission, seropositive dogs from the first test were re-examined and a second sampling was performed. Dogs with positive reactivity with one or two serological tests were sacrificed, and venous blood samples and additional organ samples were taken. After centrifugation, sera were used in second serological tests and buffy coats were tested by PCR, culture. Moreover, about $50 \mathrm{mg}$ of bone marrow, lymph node, spleen, liver and cutaneous fragments of body were used with other diagnostic tests, PCR, culture, and direct examination of Giemsa stained smears.

\section{Serological studies}

Serum samples were analyzed for antibodies to Leishmania by the indirect immunofluorescence antibody test (IFAT) and by counter-immunoelectrophoresis (CIE). IFAT was performed using a standard protocol. In brief, cell culture-derived promastigote forms of Leishmania infantum MON-1 MHOM/FR/78/LEM75 served as antigen. Sera were screened at dilutions of 1:20 to 1:2,560 in phosphate-buffered saline (PBS, $\mathrm{pH}$ 7.2). An anti-immunoglobuline canine (anti IgG dog) coupled to Fluoline was used as conjugate, at a dilution of 1:30 in PBS with $0.01 \%$ Evans blue. The reading was achieved by means of a fluorescence microscope. Results were expressed by the dilution of serum still giving fluorescence. The threshold dilution for a positive test was 1:40 (Lachaud et al., 2002, our unpublished data). CIE was performed as described by Golvan and Ambroise Thomas (1984). A positive sample presents a precipitin bands which has the specificity shown by a continuance of bands between a positive test (a serum of positive dog) and the studied sample.

\section{PCR}

DNA extraction was described by Lachaud et al. (2000). Briefly, buffy coats or tissue biopsies were placed in lysis buffer TNNT (0.5 \% Tween 20, $0.5 \%$ Nonidet P40, $10 \mathrm{mM} \mathrm{Na} \mathrm{OH}, 100 \mathrm{mM}$ Tris $\mathrm{HCl} \mathrm{pH}$ 7.6) and Proteinase $\mathrm{K}$ was added to a final concentration of $900 \mu \mathrm{g} / \mathrm{ml}$. The samples were incubated at $56^{\circ} \mathrm{C}$ for two to 12 hours followed by phenol/chloroform extraction and ethanol precipitation. $10 \mu \mathrm{L}$ of purified DNA was used for PCR reactions. Two PCR essays were used. The first one (PCR R), using primers R223 and R332 (Van Eys et al., 1992), after optimization as described previously (Chargui et al., 2005). Briefly, the following PCR condi- tions were used: the reaction was performed in a final volume of $50 \mu \mathrm{l}$ containing $10 \mu \mathrm{l}$ of sample or control DNA, $1 \times$ PCR buffer, $3 \mathrm{mM} \mathrm{MgCl} 2,0.2 \mu \mathrm{M}$ of each deoxynucleotide, $1.5 \mathrm{U}$ of Taq DNA polymerase and $60 \mathrm{pmol}$ of each primer.

The second PCR (PCR L) was performed as described by Spanakos et al. (2002) using primers Lei70 L and Lei70R, in a final volume of $50 \mu \mathrm{l}$ containing $10 \mu \mathrm{l}$ of sample or control DNA, $1 \times$ PCR buffer, $1.5 \mathrm{mM} \mathrm{MgCl}$, $0.2 \mu \mathrm{M}$ of each deoxynucleotide, $1.25 \mathrm{U}$ of Taq DNA polymerase and $100 \mathrm{pmol}$ of each primer. Reactions were cycled in an MJ Research thermocycler model PT100 using the following conditions: an initial denaturation step at $94^{\circ} \mathrm{C}$ for three $\mathrm{min}, 40$ cycles at $94^{\circ} \mathrm{C}$ for $30 \mathrm{~s}, 56^{\circ} \mathrm{C}$ for PCR R and $65^{\circ} \mathrm{C}$ for PCR L for $30 \mathrm{~s}$ and $72^{\circ} \mathrm{C}$ for $1.5 \mathrm{~min}$, and a final elongation step at $72^{\circ} \mathrm{C}$ for $10 \mathrm{~min}$.

\section{IN VITRO CULTIVATION}

Buffy coat, bone marrow, lymph node, spleen, and liver fragments were inoculated on blood agar base containing $10 \%$ rabbit blood and gentamicin $40 \mathrm{mg} / \mathrm{mL}$.

\begin{tabular}{|c|c|c|}
\hline Methode & \multicolumn{2}{|c|}{ Number positive/Total ${ }^{a}(\%)$} \\
\hline IFAT & \multicolumn{2}{|c|}{$14 / 15(93.3 \%)$} \\
\hline$\overline{\mathrm{CIE}}$ & \multicolumn{2}{|c|}{$12 / 15(80 \%)$} \\
\hline IFAT and/or CIE & \multicolumn{2}{|c|}{$15 / 15(100 \%)$} \\
\hline PCR & PCR L & PCR R \\
\hline Total & 9/9 (100\%) & $7 / 9(77.7 \%)$ \\
\hline \multicolumn{3}{|l|}{ Subgroup } \\
\hline Blood & 7/9 (77.7\%) & $5 / 9(55.5 \%)$ \\
\hline Bone marrow & $9 / 9(100 \%)$ & 7/9 (77.7\%) \\
\hline Spleen & $5 / 9(55.5 \%)$ & $3 / 9(33.3 \%)$ \\
\hline Liver & $3 / 9(33.3 \%)$ & $1 / 9(11.1 \%)$ \\
\hline Lymph node & $6 / 9(66.6 \%)$ & $4 / 9(44.4 \%)$ \\
\hline Culture, total & \multicolumn{2}{|c|}{$5 / 9(55.5 \%)$} \\
\hline \multicolumn{3}{|l|}{ Subgroup } \\
\hline Blood & \multicolumn{2}{|c|}{$5 / 9(55.5 \%)$} \\
\hline Bone marrow & \multicolumn{2}{|c|}{$3 / 9(33.3 \%)$} \\
\hline Spleen & \multicolumn{2}{|c|}{$3 / 9(33.3 \%)$} \\
\hline Liver & \multicolumn{2}{|c|}{$4 / 9(44.4 \%)$} \\
\hline Lymph node & \multicolumn{2}{|c|}{$5 / 9(55.5 \%)$} \\
\hline Direct examination, total & \multicolumn{2}{|c|}{$3 / 9(33.3 \%)$} \\
\hline \multicolumn{3}{|l|}{ Subgroup } \\
\hline Bone marrow & \multicolumn{2}{|c|}{ 3/9 (33.3\%) } \\
\hline Spleen & \multicolumn{2}{|c|}{$3 / 9(33.3 \%)$} \\
\hline Liver & \multicolumn{2}{|c|}{$3 / 9(33.3 \%)$} \\
\hline Lymph node & \multicolumn{2}{|c|}{$3 / 9(33.3 \%)$} \\
\hline Smear, culture and/or PCR & \multicolumn{2}{|c|}{ 9/9 (100\%) } \\
\hline
\end{tabular}

${ }^{a}$ total number of tested dogs positive by at least one serological method (by IFAT and/or by CIE).

Table I. - Evidence of infection by Leishmania in serologically positive dogs. 
Cultures were examined at weekly intervals for one month. Isoenzymatic identification was performed in our laboratory for positive cultures (Haouas et al., 2005) according to Rioux et al. (1990).

\section{DIRECT EXAMINATION}

Samples (bone marrow, lymph node, spleen, and liver fragments) were smeared on a glass slide, which was fixed and stained with Giemsa, and examined by light microscopy for the search of amastigotes form of Leishmania.

\section{RESULTS}

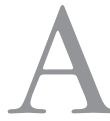
mong 250 dogs tested, all asymptomatic, 15 were seropositive by one or two methods. IFAT shown positive results in 14 cases with a title equal or higher than $1 / 40$. CIE was positive in 12 dogs.
Positive serology reactions were detected in 0-20\% of dogs according to the district, yielding a mean of $6 \%$. Of 15 dogs positive by one or two serological methods, six died before the second sampling. The nine other dogs were sacrificed and more samples were taken and evaluated by PCR, in vitro cultivation, and Giemsa strained smears. At the second sampling, five dogs were clinically ill with at least two symptoms, two dogs were suspicious (with one symptom) and two dogs were still asymptomatic. Infection was confirmed in seropositive dogs by a second serological test showing similar results, with an equal (for six dogs) or a higher (for three dogs) IFAT value than those of the first test. Same results of CIE were obtained in both first and second sampling. Infection was confirmed by at least one other method in one or more tissues. Leishmania was detected in bone marrow, blood, lymph node, spleen, and liver of respectively nine, seven, five, four, and four dogs of the nine tested dogs. Results of the

\begin{tabular}{|c|c|c|c|c|c|c|c|}
\hline $\begin{array}{c}\text { Dog } \\
\text { number }\end{array}$ & $\begin{array}{c}\text { Age } \\
\text { (year) }\end{array}$ & $\begin{array}{l}\text { Clinical status } \\
\text { (symptoms) }\end{array}$ & CIE & $\begin{array}{l}\text { IFAT } \\
\text { (title) }\end{array}$ & $\begin{array}{c}\text { Direct } \\
\text { examination } \\
\text { (tissue) }\end{array}$ & Culture (tissue) & PCR (tissue) \\
\hline 1 & 5 & $\begin{array}{l}\text { Suspicious } \\
\text { (loss of weight) }\end{array}$ & $\mathrm{P}$ & $\begin{array}{c}\mathrm{P} \\
(1 / 320)\end{array}$ & $\mathrm{N}$ & $\begin{array}{l}\text { P } \\
\text { (blood, lymph } \\
\text { node) }\end{array}$ & $\begin{array}{l}\quad \mathrm{P} \\
\text { (lymph node, bone } \\
\text { marrow) }\end{array}$ \\
\hline 2 & 5 & $\begin{array}{l}\text { Symptomatic } \\
\text { (dermatological changes, } \\
\text { loss of weight, lymph } \\
\text { node enlargement) }\end{array}$ & $\mathrm{P}$ & $\begin{array}{c}\mathrm{P} \\
(1 / 2,560)\end{array}$ & $\begin{array}{c}\mathrm{P} \\
\text { (liver, spleen, lymph } \\
\text { node, bone marrow) }\end{array}$ & $\begin{array}{l}\text { P } \\
\text { (blood, liver, spleen, } \\
\text { lymph node, bone } \\
\text { marrow) }\end{array}$ & $\begin{array}{l}\text { P } \\
\text { (blood, liver, spleen, } \\
\text { lymph node, bone } \\
\text { marrow PC) }\end{array}$ \\
\hline 3 & 6 & Asymptomatic & $\mathrm{N}$ & $\begin{array}{c}\mathrm{P} \\
(1 / 80)\end{array}$ & $\mathrm{N}$ & $\mathrm{N}$ & $\begin{array}{l}\text { P } \\
\text { (blood, bone } \\
\text { marrow) }\end{array}$ \\
\hline 4 & 4 & $\begin{array}{l}\text { Symptomatic } \\
\text { (loss of weight, lymph } \\
\text { node enlargement) }\end{array}$ & $\mathrm{N}$ & $\begin{array}{c}P \\
(1 / 640)\end{array}$ & $\begin{array}{l}\mathrm{P} \\
\text { (liver, spleen, lymph } \\
\text { node bone marrow) }\end{array}$ & $\begin{array}{l}\text { P } \\
\text { (blood, liver, spleen, } \\
\text { lymph node, bone } \\
\text { marrow) }\end{array}$ & $\begin{array}{l}\text { P } \\
\text { (blood, liver, spleen, } \\
\text { lymph node, bone } \\
\text { marrow) }\end{array}$ \\
\hline 5 & 2 & Asymptomatic & $\mathrm{N}$ & $\begin{array}{c}\mathrm{P} \\
(1 / 160)\end{array}$ & $\mathrm{N}$ & $\mathrm{N}$ & \begin{tabular}{l}
\multicolumn{1}{c}{ P } \\
(blood, bone \\
marrow, lymph \\
node)
\end{tabular} \\
\hline 6 & 1 & $\begin{array}{l}\text { Symptomatic } \\
\text { (dermatological changes, } \\
\text { loss of weight, lymph } \\
\text { node enlargement) }\end{array}$ & $\mathrm{P}$ & $\begin{array}{c}\mathrm{P} \\
(1 / 160)\end{array}$ & $\mathrm{N}$ & $\mathrm{N}$ & $\begin{array}{l}\quad \text { P } \\
\text { (blood, spleen, bone } \\
\text { marrow, lymph } \\
\text { node) }\end{array}$ \\
\hline 7 & 4 & $\begin{array}{l}\text { Symptomatic } \\
\text { (loss of weight, lymph } \\
\text { node enlargement) }\end{array}$ & $\mathrm{P}$ & $\begin{array}{c}\mathrm{P} \\
(1 / 2,560)\end{array}$ & $\begin{array}{c}\mathrm{P} \\
\text { (liver, spleen, lymph } \\
\text { node, bone marrow) }\end{array}$ & $\begin{array}{l}\text { P } \\
\text { (blood, liver, spleen, } \\
\text { lymph node, bone } \\
\text { marrow) }\end{array}$ & $\begin{array}{l}\text { P } \\
\text { (blood, liver, spleen, } \\
\text { lymph node, bone } \\
\text { marrow PC) }\end{array}$ \\
\hline 8 & 11 & $\begin{array}{l}\text { Suspicious } \\
\text { (loss of weight) }\end{array}$ & $\mathrm{P}$ & $\underset{(1 / 160)}{P}$ & $\mathrm{~N}$ & $\begin{array}{l}\mathrm{P} \\
\text { (lymph node, } \\
\text { spleen) }\end{array}$ & $\begin{array}{c}\mathrm{P} \\
\text { (bone marrow) }\end{array}$ \\
\hline 9 & 5 & $\begin{array}{l}\text { Symptomatic } \\
\text { (loss of weight, lymph } \\
\text { node enlargement) }\end{array}$ & $\mathrm{P}$ & $\begin{array}{c}\mathrm{P} \\
(1 / 20)\end{array}$ & $\mathrm{N}$ & $\mathrm{N}$ & $\begin{array}{l}\quad \text { P } \\
\text { (blood, spleen, bone } \\
\text { marrow) }\end{array}$ \\
\hline
\end{tabular}

$\mathrm{N}$ : negative result; $\mathrm{P}$ : positive result.

Table II. - Results of serological, parasitological, and molecular methods on sacrificed dogs. 
different diagnostic methods are shown in Table I. Positive results were obtained with nine, three, and five dogs respectively by PCR, direct examination, and in vitro cultivation (Table II). DNA of Leishmania was detected by PCR in all tested dogs in one or more tissues of each dog. PCR (L) was more sensitive than PCR (R), indeed two dogs were positive by PCR (L) only. Promastigotes were successfully isolated by in vitro culture from 18 tissues of five dogs. The isoenzymatic analysis showed that the isolates were all L. infantum MON-1.

\section{DISCUSSION}

E pidemiological studies of CanL have revealed a large number of asymptomatic positive animals. Many epidemiological and control studies for canine leishmaniasis are performed by serological methods (Ben Said et al., 1992; Zerpa et al., 2000). In the absence of a "gold standard" method (Reithinger et al., 2000; Lachaud et al., 2002), the sensitivity of serology could not be ascertained. Still, this study confirmed the high specificity of serology, especially IFAT, for screening of the prevalence of CVL. Indeed, all seropositive cases were confirmed as infected by at least one other diagnostic method. By contrast, four PCR-positive dogs were culture-negative. For detection of the parasite, the PCR test was more sensitive than direct examination or in vitro cultivation on most types of samples. It is interesting to note that, at least in our hands, the L method proved more sensitive than the $\mathrm{R}$ method. The latter was used previously to detect $82 \%$ of Leishmania carriers in a dog population in Southern France (Lachaud et al., 2002). Despite its low sensitivity, in vitro cultivation keeps its value for the isolation and identification of Leishmania strains. All isolated strains corresponded to Leishmania infantum MON-1 which appears as the only zymodeme involved in CanL in Tunisia (Aoun et al., 2003; Bouratbine et al., 2005). This confirms the role of the dog as the reservoir of the visceral form of human leishmaniasis in Tunisia. A relatively high positivity rate was observed in the north and the centre of Sfax governorate (Menzel Chakeur, Agareb). There are few studies on the prevalence of CL in Tunisia (Dedet et al., 1973; Ben Said et al., 1992). Ben Said et al. (1992) found a spread towards the central region as compared to Dedet et al. in 1973, with a prevalence of $6 \%$ in Enfidha Sousse which may seem low but represents a real spread as no case was observed over 91 dogs studied 20 years earlier. Moreover, a seroprevalence of $1.6 \%$ had been observed in the arid area, but no positive cases in Sfax, 30 years ago (Dedet et al., 1973). Here, we found a prevalence of $6 \%$ in Sfax in the arid area.

Our study as well as that by Ben Said et al. (1992) in the northern central of Tunisia show: $i$ ) that CanL prevalence has increased over the recent decades, and $i$ i) that it is now has a wider geographic distribution with a spread to areas that were previously non endemic. This "spatial spread" of CanL to the southern centeral area of Tunisia is correlated with the geographic extension of Human visceral leishmaniasis in the country. In a recent study, the vector specie of this form of leishmaniasis (Phlebotomus perniciosus) was abundantly found in arid area (Ghrab et al., 2006). Further studies should try to correlate these findings to epidemiological and/or climate modifications.

\section{ACKNOWLEDGEMENTS}

T This study was carried out with the financial support of the Research Unit 99-UR/08-05. We thank the Regional Directors for Public Health and Culture. We are grateful to Pr Patrick Bastien, Pr JeanPierre Dedet, and Dr Francine Pratlong (Montpellier, France) for the review of the manuscript. N. Chargui was the recipient of a grant from the Agence Universitaire de la Francophonie (AUF).

\section{REFERENCES}

Aoun K., Diouani M. F., Benikhlef R., Bouratbine A., Ben Haj Ali S., Harrat Z., Belkaid M., Kilani M. \& Ben Ismail R. Leishmania infantum MON-1: the only zymodeme isolated in canine leishmaniasis in Tunisia. Bulletin de la Société de Pathologie Exotique, 2003, 96, 77-79.

Aoun K., Kaaroud H., Hamzaoui S., Siala E., Kooli C., Turki S., Mrad S., Bouratbine A. \& Ben Maiz H. Particularities of visceral leishmaniasis in adults not infected by HIV in Tunisia. Medicine Tropicale, 2004, 64, 160-162.

Ayadi A., Ben Ismail R. \& Ben Rachid M.S. Extension de l'aire de distribution du kala-azar à Leishmania infantum (Nicolle 1908) vers le centre et le sud de la Tunisie. Archives de l'Institut Pasteur de Tunis, 1991, 68, 269-73.

Belhadj S., Djaiet-Baraket Z., Jemli B., Benosman A. \& ChaKER E. Visceral and cutaneous leishmaniases in the north. Retrospective study of cases diagnosed in the Rabta Hospital of Tunis. Bulletin de la Société de Pathologie Exotique, 1996, 89, 269-273.

Ben Said M., Jaiem A., Smoorenburg M., Semiao Santos S.J., Ben Rachid M.S. \& El Harith A. Canine leishmaniasis in the region of Enfidha (Central Tunisia). Assessment of seroprevalence with direct agglutination (DAT) and indirect immunofluorescence (IFAT). Bulletin de la Société de Pathologie Exotique, 1992, 85, 159-63.

Ben Salah A., Ben Ismail R., Amri F., Chlif S., Ben Rzig F., Kharrat H., Hadhri H., Hassouna M. \& Dellagi K. Investigation of the spread of human visceral leishmaniasis in central Tunisia. Transactions of the Royal Society of Tropical Medicine and Hygiene, 2000, 94, 382-386.

Besbes A., Pousse H., Ben Said M., Kharrat H. \& Ghenimi L. Leishmanioses viscérales infantiles du centre tunisien (221 cas). Médecine et Maladies Infectieuses, 1994, 24, 628-634. 
Bouratbine A., Aoun K., Chahed M. \& Ben Ismail R. Données épidémiologiques sur la leishmaniose viscérale infantile en Tunisie. Médecine et Maladies Infectieuses, 1998, 28, 446447.

Chargui N., Bastien P., Kallel K., Haouas N., Messaidi Akrout F., Masmoudi A., Zili J., Chaker E., Dhahri Ben Othman A., Azaiez R., Crobu L., Mezhoud H. \& Babba H. Usefulness of PCR in the diagnosis of cutaneous leishmaniasis in Tunisia. Transactions of the Royal Society of Tropical Medicine and Hygiene, 2005, 99, 762-768.

Dedet J.P., Osman F.B., Chadli A., Croset H. \& Rioux J.A. Leishmaniasis in Tunisia. Sero-immunological survey about the frequency of infestation (author's transl). Annals of Tropical Medicine and Parasitology, 1973, 48, 653-660.

Ghrab J., Rhim A., Bach-Hamda D., Chahed M.K., Aoun K., Noura S. \& Bouratbine A. Phlebotominae (Dipteria: Psychodidae) of human leishmaniasis sites in Tunisia. Parasite, 2006, 3, 23-33.

Golvan Y.J. \& Ambroise-Thomas P. Les nouvelles techniques en parasitologie et immuno-parasitologie, second edition. Médecine-Sciences, Flammarion, Paris, 1984.

Haouas N., Chargui N., Chaker E., Ben Said M., Babba H., Belhadj S., Kallel K., Pratlong F., Dedet J.P., Mezhoud H. \& AzAiez R. Anthroponotic cutaneous leishmaniasis in Tunisia: presence of Leishmania killicki outside its original focus of Tataouine. Transactions of the Royal Society of Tropical Medicine and Hygiene, 2005, 99, 499-501.

Lachaud L., Dereure J., Chabbert E., Reynes J., Mauboussin J.M., Eric Oziol J., Dedet J.P. \& Bastien P. Optimized PCR using patient blood samples for diagnosis and follow-up of visceral leishmaniasis, with special reference to AIDS patients. Journal of Clinical Microbiology, 2000, 38, 236240.

Lachaud L., Chabbert E., Dubessay P., Dereure J., Lamothe J., DEDET J.P. \& BASTIEN P. Value of PCR methods for diagnosis and prevalence of canine visceral leishmaniasis and detection of asymptomatic carriers. Parasitology, 2002, 125, 197-207.

Nicolle C. \& COMTE M. Recherches sur la kala-azar entreprises à l'Institut Pasteur de Tunis, IV. Origine canine du kala-azar. Archives de l'Institut Pasteur de Tunis, 1908, 3, 59-62.

Reithinger R., Lambson B.E., Barker D.C. \& Davies C.R. Use of PCR to detect Leishmania (Viannia) spp. in dog blood and bone marrow. Journal of Clinical Microbiology, 2000, 38, $748-751$.

Rioux J.A., Lanotte G., Serre E., Pratlong F., Bastien P. \& Périeres J. Taxonomy of Leishmania. Use of isoenzymes suggestions for new classification. Annales de Parasitologie Humaine et Comparée, 1990, 65, 111-125.

Spanakos G., Patsoula E., Kremastinou T., Sarolgou G. \& VAKALIS N. Development of a PCR-based method for diagnosis of Leishmania in blood samples. Molecular Cell Probes, 2002, 16, 415-420.

Van Eys G.J., Schoone G.J., Kroon C.C.M. \& Ebeling S.B. Sequence analysis of small subunit ribosomal RNA genes and its use for detection and identification of Leishmania parasites. Molecular and Biochemical Parasitology, 1992, 51, 133-142.
Zerpa O., Ulrich M., Negron E., Rodriguez N., Centeno M., Rodriguez V., Barrios R.M., Belizario D., Reed S. \& Convit J. Canine visceral leishmaniasis on Margarita island (Nueva Esparta, Venezuela). Transactions of the Royal Society of Tropical Medicine and Hygiene, 2000, 94, 484-487.

Reçu le 11 décembre 2006 Accepté le 11 mai 2007 